\title{
Validity and reliability analyses for the climate of science subjects research tool
}

\begin{abstract}
The climate belongs amongst the most critical dimensions that influences to effective teaching and learning. In terms of science subjects, the climate is rarely discussed in researches all over the world. The main aim of the research was to adapt a research tool regarding the climate in science subjects. The research sample consisted of 121 pupils of the 7th and 8th grades of elementary school and the questionnaire included 26 items. Constructive validity of the questionnaire was assessed by means of an exploratory factor analysis, which divided items into three factors. The loading values of all items varied between 0.45 and 0.88 and explained $69.55 \%$ of the total variance. By using Cronbach's alpha coefficient as an internal consistency, it resulted in a value of 0.89 . The results showed that a research tool can be used as a valid and reliable instrument in further research.
\end{abstract}

Keywords: climate, reliability, science subjects, validity, climate, exploratory factor, analysis,
Volume 2 Issue 4 - 2018

\section{Milan Kubiatko, Helena Grecmanova, Kristyna Balatova, Eva Urbanovska, Vlasta Cabanova}

Department of Pedagogical Studies, University of Zilina, Faculty of Humanities, Slovakia

Correspondence: Milan Kubiatko, Department of Pedagogical Studies, University of Zilina, Faculty of Humanities, Univerzitna I, 01026 Zilina, Slovakia, Email mkubiatko@gmail.com

Received: August 01, 2018 | Published: August 07, 2018

\section{Introduction}

The concept of school or learning climate does not have a clear and definite definition. The definition is described in the older works e.g, ${ }^{1}$ but also in the newer ones. ${ }^{2}$ There is also a problem with the concepts; the concept "learning climate" is used in a significant lower amount of cases, as the more used term is "school climate". However, in many papers these two concepts are conceived as synonyms. Moreover, many authors only used the term "climate". In our case, the term "school climate" or only "climate" was used throughout the paper. $\mathrm{As}^{3}$ showed, there is variability in individual perceptions of a school's climate, and researchers propose that it is the subjective perception of the environment that influences individual student outcomes considered the school climate as a critical dimension that is linked to effective teaching and learning. A similar definition is possible to find in other works. ${ }^{5,6} \mathrm{It}$ is appropriate to mention that the first description of the definition of the term "school climate" is possible to find in the work of. ${ }^{7}$ However, it took nearly 50 years until this concept was adequately examined and received a place in the educational research. ${ }^{4}$ The examination of the school climate amongst pupils is part of the portfolio of many researches. Hence, in the text below, an outline of selected research works regarding the school climate can be found and at the end of this text, research works are presented which relate to the school climate in science subjects.

Many papers were focused on the problematic relationship between the school climate and the pupils' achievements, because the school climate is a crucial factor in for explaining the pupils' achievements and outcomes. ${ }^{8-10}$ Similar results are possible to be found in older studies ${ }^{11}$ examined the relationship between the school climate and the children's academic and social development in elementary school. The results indicated that the overall school climate and the teacherstudents relationship significantly influenced the school adjustment. The school climate significantly influenced the pupils' achievements in reading and mathematics. A similar result is found in the research of, Haynes, MacNeil et al., ${ }^{12,13}$ Prater an used standardized tests as research tools for the examination of the influence of the school climate on achievement. Authors stated the positive influence of the school climate on achievement in standardized tests ${ }^{13}$ revealed that a mastery climate accounted to higher levels of academic competence in the first year of middle school. A moderate effect was found, in which greater attachment security to the mother appeared to lessen the relationship between a performance climate and anxiety symptoms during the transition to middle school. Some researches asserted positive correlations between the school climate and the motivation to learn. ${ }^{14}$ A positive school climate also had a positive effect on the mental health of high school pupils. ${ }^{15}$

Furthermore, the positive school climate had a significant influence on drug addiction. If the school climate was positive, a low level could be seen in the occurrence and use of drugs by pupils at school. ${ }^{16,17}$ The positive school climate significantly affected the level of violence and bullying amongst pupils. ${ }^{18-21}$ Other factors which are influenced by the school climate can be found in an overview of a study of. ${ }^{22}$ The problematic aspects of the school climate in science subjects are examined very marginally; they mainly concern works which focus on scientific concepts of the general climate at school and in the classroom ${ }^{23-26}$ focused on the effect of the school climate and on the choice of elective subjects during learning. If the school climate was perceived positively during the teaching of science subjects, then pupils chose elective science subjects. Similar results were found in other research works ${ }^{27-29}$ examined three factors: the school (classroom) climate, interest about science subjects and the use of innovative methods during teaching. Authors found out, that when teachers used innovative teaching methods (no frontal teaching), then the climate at school was more positive and the interest in science subjects increased ${ }^{30}$ examined more factors regarding the school climate during Physical Education. The authors clarified that the teachers' leadership style had a positive effect on the school climate and on the interest in subjects. It is also possible to find research studies focused on the evaluation of school climate instruments. In the majority of cases, the authors of these studies used an exploratory factor analysis, a determination of reliability and also an item-total correlation. ${ }^{31} \mathrm{~A}$ similar approach was used in the study of ${ }^{21-32}$ adapted a research tool regarding the school climate amongst Brazilian elementary school pupils. These authors showed that there is a small amount of school climate studies regarding the adaptation process of questionnaires Similar results were found in studies with a different focus. ${ }^{33-37}$ 


\section{Aims of the research}

The main aim of the research was to adapt a research tool regarding the climate in science subjects. It was used in a questionnaire, in which items were put on a scale. All participants were informed about the purpose of the research before completing the questionnaire. The questionnaire was administered in a pen-paper format during lessons of biology.

\section{Methods}

\section{Respondents}

The sample was collected from two elementary schools. The research sample consisted of 121 pupils of the 7th and 8th grade (13-15 years). This sample is appropriate for studies as the validation and adaptation of a research tool is realized. ${ }^{38}$ The average age of respondents was 14.02 years. The number of respondents from the 7 th grade was 58 and the rest of them $(n=63)$ was from the 8th grade. The participation of students of the research was voluntary, so this fact led to a relatively low amount of respondents in the entire research. All the respondents had got an experience with every science subject (biology, physics and chemistry).

\section{Preparation of Items}

Since the questionnaire was intended to determine the school climate in science subjects, literary sources were reviewed for similar research tools over the world. After the literature review, the initial research tool with 38 items was created. Next, items were reviewed by three experts of education methodology, who worked on the university environment, its readability, its representation of content and how well the items are likely to measure climate in the science subjects. Twelve items were eliminated for the inconsistency with other items. The final questionnaire included 26 items. Respondents were asked to respond to each item using a 5-point Likert scale regarding to the determination of the school climate: never, sometimes, often, usually or always. The questionnaire started with the sentence: "Please evaluate how you perceive the learning process in science subjects". A similar procedure was found in the work of Kurbanogl et al., ${ }^{39}$ The responses of respondents were coded: never-1, sometimes-2, often -3 , usually -4 , always -5 .

\section{Procedure}

Before administration of the instrument, all respondents were informed about the purposes of the research. All respondents were assured that the research was anonymous and that all the data was only going to be used for research purposes. The administration took approximately 15 minutes and all the questionnaires were filled in correctly and the data were included into analyses. The analysis of the data was put in two divisions: (a) determination of reliability by using the Cronbach alpha coefficient and calculating the item total correlation to obtain the internal consistent reliability estimates of the scale scores and (b) testing the construct validity by means of the exploratory factor analysis. SPSS 22.0 and Statistica 10.0 software were used for statistical analyses.

\section{Results}

For construct validity, an exploratory factor analysis was conducted to validate the underlying structure of the model. For using the factor analysis, the Kaiser-Meyer-Olkin (KMO) measure of sampling adequacy and Bartlett's test of sphericity were used. ${ }^{40}$ The value of the KMO test was 0.87 and the values of the Bartlett's test of sphericity was $\left(\chi^{2}=1215.59 ; p<0.001\right)$. Both values showed that the relationship between the variables was strong and appropriate for a factor analysis. ${ }^{41}$ Items were divided into three dimensions see Table 1:

I. The teacher's style of teaching (11 items),

II. The meaningfulness of the teaching process ( 8 items),

III. Fair approach of teacher toward pupils (6 items). These dimensions explained $69.55 \%$ of total variance, and the most variance was explained by the first dimension $(36.25 \%)$.

Table I Results of the factor analysis

\begin{tabular}{|c|c|c|c|}
\hline & I. & II. & III. \\
\hline The rules during the learning process are strictly determined. & 0.66 & 0.21 & -0.15 \\
\hline The tasks have to be done precisely and reliably. & 0.75 & 0.18 & 0.2 \\
\hline The tasks are controlled continuously. & 0.55 & 0.32 & -0.12 \\
\hline The tasks are in line with what I learned. & 0.88 & 0.1 & 0.09 \\
\hline I manage the home preparation of the learning process without problems. & 0.59 & 0.29 & 0.02 \\
\hline The teacher is teaching interestingly and with enthusiasm. & 0.51 & 0.09 & 0.3 \\
\hline The teacher is using explanatory examples and aids. & 0.45 & 0.22 & 0.19 \\
\hline The teacher asks us what we know about a new topic, before he/she begins to explain a new topic. & 0.84 & 0.1 & -0.09 \\
\hline The teachers is focused on the actual topic, he/she does not talk about other topics. & 0.72 & 0.12 & 0.13 \\
\hline The teacher keeps my attention by his/her teaching style. & 0.56 & -0.16 & -0.05 \\
\hline The teacher answers questions of pupils. & 0.62 & -0.08 & 0.16 \\
\hline I have to explain my opinion. & 0.18 & $0.5 \mathrm{I}$ & 0.22 \\
\hline I can apply my good ideas during the learning process. & 0.11 & 0.65 & -0.15 \\
\hline The learning process also takes place outside of school. & -0.21 & 0.59 & -0.12 \\
\hline
\end{tabular}


Table Continued

\begin{tabular}{|c|c|c|c|}
\hline & I. & II. & III. \\
\hline The teacher explains us how and where to use the elements which we learned during class. & 0.08 & 0.74 & 0.12 \\
\hline The teacher tells us in which profession it is possible to use a topic being taught in class. & 0.11 & 0.7 & 0.15 \\
\hline The teacher is trying to find out if we understand the topic during the examination process. & 0.17 & 0.49 & 0.31 \\
\hline We are working in groups during the learning process. & 0.05 & 0.82 & -0.1 \\
\hline The teacher leads us, to discuss about procedures by the solving of tasks. & 0.09 & 0.74 & 0.1 \\
\hline I share my opinion to with the teacher without fear. & -0.03 & -0.06 & 0.89 \\
\hline The teacher supports me if I am interested in a specific topic. & 0.12 & 0.22 & 0.65 \\
\hline When I have problems with solving tasks, the teacher helps me. & 0.31 & 0.02 & 0.45 \\
\hline When I am faster than other schoolmates in solving tasks, the teacher gives me another task. & 0.12 & 0.13 & 0.68 \\
\hline The results of my works in school are evaluated fairly. & -0.19 & 0.11 & 0.73 \\
\hline I am in a good mood before the examination process. & 0.21 & -0.09 & 0.58 \\
\hline Eigen values & 7.23 & 3.22 & 1.49 \\
\hline$\%$ of variance & 36.25 & 19.18 & 14.12 \\
\hline
\end{tabular}

According to ${ }^{42}$ the prime factor should explain at least 20 percent of the total variance and the difference between the second and the third factor should be lower than the difference between the first and the second factor. The critical value for inclusion of an item to a dimension was 0.40 . The numbers of items are identical to the numbers in the questionnaire. The reliability of the questionnaire was calculated using Cronbach's alpha coefficient. The value of reliability was high $(\alpha=0.89)$, which indicated an acceptable reliability of the questionnaire. ${ }^{43}$ The high value of reliability coefficient in our study implies that the instrument used for investigation of the climate in science subjects was reliable and its usage for further analysis was appropriate. Values of Cronbach's alpha for specific factors (areas) were between $0.62-0.85$. According to, ${ }^{44,45}$ a reliability score between 0.59 and 0.75 can be considered acceptable. The analyzed result of the corrected item-total correlation of the 26 items ranged from 0.49 to 0.82 .

\section{Discussion and conclusion}

The main aim of the study was to evaluate a research tool regarding the climate in the learning process of science subjects. For the evaluation process, the methods of multidimensional statistics were used as an exploratory factor analysis and a determination of reliability was established by using Cronbach's alpha coefficient and total-item correlation. A similar approach was used for example in the study of ${ }^{31}$ and in another study conducted by Kohl. ${ }^{46}$ The value of reliability of the research tool was appropriate for the questionnaire and it is possible to use it in other researches. The value of Cronbach's alpha was higher than 0.70 , which is in concordance with the methodology literary sources, which made this value appropriate. ${ }^{43}$ Also, the values for the factors gave appropriate values. It is also comparable with other sources like. ${ }^{47}$ The use of the factor analysis for the determination of construct validity, showed acceptable results, the items of research tool were distributed into three factors and all conditions for the use of the exploratory factor analysis were respected. During the use of the factor analysis, it was accepted that one item in one factor and every factor loading score for the item was higher than 0.40 . This rule was also mentioned in the work of. ${ }^{48}$ In conclusion, the adaptation process required special attention. The adapted research tool, which is validated and which has been found reliable, could be used in the main research. This result is also an indicator, that the questionnaire could be used universally. Although the sample size included lower secondary school pupils, it could be tested in high schools as well. In the main research, the sample size will be higher due to the different goals and conditions of this research. The statistical methods are planning to use with the respect to determined aims in the main research. ${ }^{49}$

\section{Acknowledgements}

This paper is supported by the grant VEGA No. 1/0239/17 - The climate of the teaching of science subjects: creating and implementation of a research tool.

\section{Conflict of interest}

The author declares there is no conflict of interest.

\section{References}

1. Tagiuri R. The Concept of Organizational Climate. In R Tagiuri, GH Litevin editors. Organizational climate: Explanation of a concept. Boston: Harvard University Press; 1968. p. 11-35.

2. Cohen J, McCabe EM, Michelli NM, et al. School Climate: Research, Policy, Practice, and Teacher Education. Teachers College Record. 2009;111(1):180-213.

3. Loukas A. What Is School Climate? High-quality School Climate is Advantageous for all Students and may be Particularly Beneficial for At-risk Students. Leadership Compass. 2007;5(1):1-3.

4. Cohen J. Social, Emotional, Ethical and Academic Education: Creating a Climate for Learning, Participation in Democracy and Well-being. Harvard Educational Review. 2006;76(2):201-237.

5. Anderson CS. The Search for School Climate: A Review of the Research. Review of Educational Research. 1982;52(3):368-420.

6. Kuperminc G, Leadbeater BJ, Emmons C. Perceived School Climate and Problem Behaviors in Middleschool Students: The Protective Function of a Positive Educational Environment. Journal of Applied Developmental Science. 1997;1(1):76-88. 
7. Perry A. The Management of a City School. New York: Macmillan. 1908.

8. Hampden-Thompson G, Galindo C. School-family Relationships, School Satisfaction and the Academic Achievement of Young People. Educational Review. 2017;69(2):248-265.

9. Reynolds KJ, Lee E, Turner I, et al. How Does School. Climate Impact Academic Achievement? An Examination of Social Identity Processes. School Psychology International. 2017;38(1):78-97.

10. Wang MT, Degol JL. School Climate: A Review of the Construct, Measurement, and Impact on Student Outcomes. Educational Psychology Review. 2015;(17)2:1-38.

11. Esposito C. Learning in Urban Blight: School Climate and its Effect on the School Performance of Urban, Minority, Low-income Children. School Psychology Review. 1999;28(3):365-377.

12. Haynes NM, Emmons C, Ben-Avie M. School Climate as a Factor in Student Adjustment and Achievement. Journal of Educational and Psychological Consultation. 1997;8(3):321-329.

13. MacNeil AJ, Prater DL, Busch S. The Effects of School Culture and Climate on Student Achievement. International Journal of Leadership in Education: Theory and Practice. 2009;12(1):73-84.

14. Nelson RM. Achievement Motivation in Adolescents: The Role of Peer Climate and Best Friends. Journal of Experimental Education. 2008;76(2):170-189.

15. Lester L, Cross D. The Relationship Between School Climate and Mental and Emotional Wellbeing Over the Transition from Primary to Secondary School. Psychology of Well-Being. 2015;5(1):1-15.

16. Reid RJ, Peterson NA, Hughey J, et al. School Climate and Adolescent Drug Use: Mediating Effects of Violence Victimization in the Urban High School Context. Journal of Primary Prevention. 2006;27(3):281292.

17. Syvertsen AK, Flanagan CA, Stout MD. Code of Silence: Students' Perceptions of School Climate and Willingness to Intervene in a Peer's Dangerous Plan. Journal of Educational Psychology. 2009;101(1):219232.

18. Benbenishty R, Astor RA, Roziner I, et al. Testing the Causal Links Between School Climate, School Violence, and School Academic Performance: A Cross-Lagged Panel Autoregressive Model. Educational Researcher. 2016;45(3):197-206.

19. Han Z, Zhang, G, Zhang H. School Bullying in Urban China: Prevalence and Correlation with School Climate. International Journal of Environmental Research and Public Health. 2017;(1):1-13.

20. Laftman SB, Ostberg V, Modin B. School Climate and eExposure to Bullying: a Multilevel Study. School Effectiveness and School Improvement. 2017;28(1):153-164.

21. Kohl D, Recchia S, Steffgen G. Measuring School Climate: An Overview of Measurement Scales. Educational Research. 2013;55(4):411-426.

22. Thapa A, Cohen J, Guffey S, et al. A Review of School Climate Research. Review of Educational Research. 2013;83(3):357-385.

23. Blomberg G, Sturmer K, Seidel T. How Pre-service Teachers Observe Teaching on Video: Effects of Viewers' Teaching Subjects and the Subject of the Video. Teaching and Teacher Education. 2011;27(7):1131-1140.

24. Nolen SB. Learning Environment, Motivation, and Achievemen in High School Science. Journal of Research in Science Teaching. 2003;40(4):347-368.

25. Walberg HJ, Anderson GJ. Classroom Climate and Individual Learning. Journal of Educational Psychology. 1968;59(6):414-419.
26. Lazarowitz R, Lazarowitz RH. Choices and Preferences of Science Subjects by Junior High School Students in Israel. Journal of Research in Science Teaching. 1979;16(4):317-323.

27. Cantrell P, Young S, Moore A. Factors Affecting Science Teaching Efficacy of Preservice Elementary Teachers. Journal of Science Teacher Education. 2003;14(3):177-192.

28. Smyth E, Hannen C. School Effects and Subject Choice: The Uptake of Scientific Subjects in Ireland. School Effectiveness and School Improvement: An International Journal of Research, Policy and Practice. 2016;17(3):303-327.

29. Fiksl M, Flogie A, Abersek B. Innovative Teaching/Learning Methods To Improve Science, Technology And Engineering Classroom Climate And Interest. Journal of Baltic Science Education. 2017;16(6):10091019 .

30. Jiang Z, Jia ZR. Effects of Physical Education Teachers' Leadership Styles and Classroom Climate on Learning Motivation for Basketball Course. Eurasia Journal of Mathematics, Science and Technology Education. 2018;14(4):1351-1357.

31. Cavanaugh S, Simmons P. Evaluation of a School Climate Instrument for Assessing Affective Objectives in Health Professional Education. Evaluation \& Health Professions. 1997;20(4):455-478.

32. Petrucci GW, Borsa JC, Damasio BF. Adaptation and Preliminary Validation Evidences of the School Climate Questionnaire - Revised, Elementary and Middle School Version (SCS-MS). Psicologia: Reflexão e Crítica. 2016;29(1):25-32.

33. Bilgin H, Oznacar B. Development of the Attitude Scale Towards Crisis and Chaos Management in Education. Eurasia Journal of Mathematics, Science and Technology Education. 2017;13(11):7381-7389.

34. Chroustova K, Bilek M, Sorgo A. Validation of Theoretical Constructs toward Suitability of Educational Software for Chemistry Education: Differences between Users and Nonusers. Journal of Baltic Science Education. 2017;16(6):873-897.

35. Ergun B. Development and Validation of an Instrument to Measure Secondary School Science Students' Social Capital Scale. Eurasia Journal of Mathematics, Science and Technology Education. 2017;13(12):7771-7781.

36. Sizova ZM, Semenova TM, Zvonnikov TI, et al. The Development of Model and Measuring Tool for Specialists Accreditation in Area of Public Health Services. Eurasia Journal of Mathematics, Science and Technology Education. 2017;13(10):6779-6788.

37. Temel S, Sen S, Ozcan O. Validity and Reliability Analyses for the Nature of Science Instrument Secondary (NOSI-S). Journal of Baltic Science Education. 2017;16(3):429-437.

38. Tsang S, Royse CF, Terkawi AS. Guidelines for Developing, Translating, and Validating a Questionnaire in Perioperative and Pain Medicine. Saudi Journal of Anaesthesia. 2017;11(1):80-89.

39. Kurbanoglu NI, Takunyaci M. Development and Evaluation of an Instrument Measuring Anxiety Toward Physics Laboratory Classes among University Students. Journal of Baltic Science Education. 2017;16(4):592-598.

40. Temel S, Sen S, Yilmaz A. Validity and Reliability Analysis for Chemistry Self-concept Inventory. Journal of Baltic Science Education. 2015;14(5):599-606.

41. Thompson B. Exploratory and Confirmatory Factor Analysis: Understanding Concepts and Applications. Washington, DC, US: American Psychological Association; 2004. p. 195. 
42. Reckase MD. Unifactor Latent Trait Models Applied to Multifactor Tests: Results and Implications. Journal of Educational Statistics. 1979;4(3):207-230.

43. Nunnally JC. Psychometric Theory. New York: McGraw-Hill. 1978.

44. Dhindsa HS, Chung G. Attitudes and Achievement of Bruneian Science Students. International Journal of Science Education. 2003;25(8):907922.

45. Francis LJ, Greer JE. Attitude Toward Science Among Secondary School Pupils in Northern Ireland: Relationship with Sex, Age and Religion. Research in Science and Technological Education. 1999;17(1):67-74.

46. Steffgen G, Recchia S, Viechtbauer W. The Link Between School Climate and Violence in School: A Meta-analytic Review. Aggression and Violent Behavior. 2013;18(2):300-309.
47. Drummond C, Fischhoff B. Development and Validation of the Scientific Reasoning Scale. Journal of Behavioral Decision Making. 2015;30(1):26-38.

48. Velicer WF, Fava JL. Effects of Variable and Subject Sampling on Factor Pattern Recovery. Psychological Methods. 1998;3(2):231-251.

49. Maltais C, Duchesne S, Ratelle CF, Learning Climate, Academic Competence, and Anxiety During the Transition to Middle School: Parental Attachment as a Protective Factor. European Review of Applied Psychology. 2017;67(2):103-112. 